\title{
Persepsi Pengusaha UMKM Dan Organizational Change Readiness Dalam Penerapan Standar Akuntansi Keuangan Entitas Mikro Kecil Dan Menengah
}

\author{
Gede Mandirta Tama ${ }^{1 *}$, Made Kony Koswara ${ }^{2}$, Anantawikrama Tungga Atmadja ${ }^{3}$, M. \\ Rudi Irwansyah ${ }^{4}$
}

1,2, Pusat Pendidikan dan Pelatihan INATA, Singaraja - Indonesia

3,4Universitas Pendidikan Ganesha, Singaraja - Indonesia

\author{
A R T I C L E I N F O \\ Article history: \\ Received 30 September \\ 2018 \\ Received in revised form \\ 5 October 2018 \\ Accepted 29 November \\ 2018 \\ Available online 12 \\ December 2018

Kata Kunci:
Persepsi Pengusaha UMKM,
Organizational Change
Readiness, dan Standar
Akuntansi Entitas Mikro
Kecil dan Menengah
Keywords:
Perceptions of
Entrepreneurs of Micro and
Small and Medium
Enterprises, Organizational
Change Readiness, and The
Application of Accounting
Standards for Small and

A B S T R A C T
A B S T R A K

Penelitian ini bertujuan untuk menguji pengaruh persepsi pengusaha UMKM dan organizational change readiness terhadap penerapan standar akuntansi entitas mikro kecil dan menengah. Populasi dalam penelitian ini adalah Usaha Mikro Kecil dan Menengah (UMKM) di Kabupaten Buleleng sebanyak 32.756 UMKM, dengan menggunakan teknik probability sampling dengan simple random sampling dan rumus slovin sehingga sampel penelitian ini sebanyak 100 sampel. Analisis data penelitian menggunakan analisis regresi linier berganda dengan menggunakan program Statistical Package for Social Science (SPSS) v.20. Hasil penelitian ini menyatakan bahwa persepsi Pengusaha UMKM dan organizational change readiness memiliki pengaruh signifikan positif terhadap penerapan standar akuntansi entitas mikro kecil dan menengah.

This study aims to examine the effect of perceptions of entrepreneurs of Micro and Small and Medium Enterprises and organizational change readiness on the application of accounting standards for small and medium micro entities. The population in this study were Micro, Small and Medium Enterprises (UMKM) in Buleleng Regency as many as 32,756 UMKM, using probability sampling techniques with simple random sampling and Slovin formulas so that the sample of this study was 100 samples. Research data analysis used multiple linear regression analysis using the Statistical Package for Social Science (SPSS) v.20 program. The results of research stated that the perceptions of entrepreneurs of Micro and Small and Medium Enterprises and organizational change readiness had a significant positive effect on the application of accounting standards for small and medium micro entities.

Copyright (C) Ekuitas: Jurnal Pendidikan Ekonomi. All rights reserved.

\section{Pendahuluan}

Perkembangan perekonomian Indonesia sampai saat ini, tidak terlepas dari peran dan kontribusi dunia usaha seperti Usaha Mikro Kecil dan Menengah (UMKM). Peranan dan Kontribusi UMKM sangat dibutuhkan didalam perekonomian nasional, yang mana kontribusi tersebut meliputi Produk Domestic

\footnotetext{
* Corresponding author.

E-mail addresses: mandirta.tama27@gmail.com (Gede Mandirta Tama)
} 
Bruto (PDB) setiap tahunnya, penciptaan lapangan pekerjaan, mampu memberdayakan masyarakat sehingga dapat mengadopsi budaya lokal dalam usahanya yang dapat membedakan usaha satu dengan usaha lainnya, mampu menciptakan pasar baru dan penciptaan ide-ide baru yang dapat menginspirasi bagi kalangan muda.

Namun, perkembangan UMKM yang dapat dilihat saat ini, tidak terjadi begitu saja. Akan tetapi perjalanan UMKM dalam kiris yang dialami pada tahun 1997 sampai 1998 membuktikan bahwa UMKM mampu keluar dari kondisi tersebut sehingga tetap berdiri kokoh dan mampu memberikan kontribusinya saat itu (Bank Indonesia dalam Afianti, 2017). Oleh karena itu, keberadaan UMKM telah diakui oleh seluruh kalangan masyarakat Indonesia, sebagai usaha yang dapat berdiri kokoh dan menjadi usaha yang mudah untuk didirikan dengan tingkat risiko yang rendah jika dibandingkan dengan membuka usaha besar serta menyentuh langsung kehidupan masyarakat. Dengan demikian perkembangan UMKM di Indonesia terus mengalami perkembangan dengan pesat. Tidak kalah pentingnya di Kabupaten Buleleng, yang mana dalam penelitian ini sebagai lokasi penelitian yang menunjukkan bahwa perkembangan UMKM dari tahun ke tahun mengalami peningkatan jumlah UMKM yang tersebar baik di perkotaan maupun pedesaan. Namun, disisi yang berbeda dalam perkembangan saat ini, UMKM dihadapkan pada sejumlah permasalahan atau kendala yang menghambat perkembanganya yakni minimnya kualitas sumber daya manusia, pemahaman terhadap manajemen usaha dan keuangan UMKM minim, minimnya akses permodalan dan kurangnya produktivitas UMKM (wartaekonomi.co.id),dipaparkan bahwa sebagai besar pengusaha UMKM gagal menjalankan usahanya bukan karena produknya tidak memiliki pasar, tetapi terkait dengan permasalahan pembukuan yang tidak terkelola dengan baik.

Terlepas dari permasalahan pengelolaan usahanya, UMKM memiliki kendala didalam pengelolaan keuangan usahanya. Pengelolaan keuangan UMKM, memerlukan sumber daya manusia yang mampu memahami dan terampil dalam akuntansi baik pencatatan/pembukuan maupun laporan keuangan. Pengelolaan keuangan yang baik akan dapat mencerminkan pengelolaan usaha yang baik. Terlebih laporan keuangan yang dibuat UMKM akan dapat memberikan informasi relevan terkait dengan keputusankeputusan bisnis dan menjadikan sebagai syarat untuk mengajukan kredit dalam penambahan modal usaha. Namun pada kenyaatnnya, pegusaha UMKM memiliki keterbatasan didalam pengetahuan dan keterampilan terkait akuntansi dari aspek pembukuan maupun laporan keuangan yang akan dibuat. Selain itu, adanya anggapan laporan keuangan yang dibuat bukan sesuatu yang penting dan tidak berpengaruh pada usahanya (Rudiantoro dan Siregar, 2012). Selain itu, untuk menyusun laporan keuangan harus sesuai standar akuntansi keuangan. Standar akuntansi yang diterapkan menyulitkan pengusaha UMKM untuk memahami dan menerapkannya didalam laporan keuangan yang dibuat. Hal ini dikarenakan, standar akuntansi yang diterapkan memiliki standar tinggi yang belum disesuaikan dengan kondisi lapangan/usaha sehingga sulit dipahami oleh UMKM.

Oleh karena itu, untuk mempermudah UMKM didalam memahami penyusunan laporan keuangan dan pentingnya standarisasi laporan keuangan untuk kesamaan persepsi (Afianti, 2017), maka Dewan Standar Akuntansi Keuangan (DSAK) Ikatan Akuntan Indonesia (IAI) mengisyaratkan untuk enititas tanpa akuntabilitas publik salah satunya adalah UMKM dapat menerapankan Standar Akuntansi Keuangan Entitas Tanpa Akuntabilitas Publik (SAK ETAP). Tujuan diterapkannya SAK ETAP ini untuk ketersediaan laporan keuangan usaha yang dapat digunakan sebagai mana mestinya. Namun didalam penerapannya, SAK ETAP masih belum diterapkan dengan baik dan maksimal oleh pelaku usaha terutama UMKM. Penelitian yang dilakukan oleh Fatwa (2016) pada UKM Penggilingan Padi menyatakan bahwa UKM belum menerapkan SAK ETAP, yang mana laporan yang dibuat hanya berupa laporan neraca dan laporan laba/rugi, keberadaan SAK ETAP belum banyak diketahui oleh pengusaha UKM dan kurangnya sumber daya manusia yang memahami dan kemampuan untuk menyusun laporan keuangan sesuai SAK ETAP, tidak tersedia pembagian tugas dan ketidakharusan penggunaan SAK ETAP. Kesederhanaan didalam standar akuntansi dan ketersediaan sumber daya manusia yang dapat memahami laporan keuangan yang disesuaikan dengan standar akuntansi yang berlaku serta adanya sosialisasi yang baik, UMKM dapat menerapkan standar ini kedalam laporan keuangan.

Kebutuhan akan tersedianya standar akuntansi yang lebih sederhana dari SAK UMUM dan SAK ETAP tentu diharapkan oleh pengusaha terutama pengusaha UMKM. Hal ini dikarenakan, ketersediaan sumber daya manusia dalam UMKM untuk menghasilkan sebuah laporan keuangan masih minim sehingga perlunya penyusunan dan diterapkannya standar akuntansi yang lebih sederhana dari SAK sebelumnya. Oleh karena itu, DSAK IAI melakukan pengembangan standar akuntansi yang lebih sederhana sehingga dapat menghadirkan SAK yang dapat diterapkan oleh UMKM yang dapat memerikan peningkatan kemajuan EMKM (IAI, 2016). SAK ini adalah Standar Akuntansi Keuangan Bagi Entitas Mikro, Kecil dan Menengah (SAK EMKM), yang mana standar ini ditujukkan kepada UMKM. Penerapan SAK EMKM pada UMKM memerlukan sosialisasi, persiapan sumber daya manusia, pemahaman atau pengetahuan (Fatimah dan 
Wijayana, 2017). Selain itu, persepsi pengusaha UMKM terkait kemudahan penggunaan dan pemanfaatan, dan adanya kesiapan UMKM untuk melakukan perubahan menjadi penting didalam penerapan SAK EMKM.

Penelitian ini akan berfokus pada dua aspek tersebut yakni persepsi pengusaha UMKM dan kesiapan organisasi untuk berubah (organizational change readiness). Persepsi pengusaha UMKM yang baik pastinya akan memberikan penerapan yang baik pula. Persepsi kegunaan dan kemudahan penggunaan menjadi salah satu indikator didalam penerapan standar akuntansi. Selain dilihat pada persepsi pengusaha UMKM, tentu pula melihat kesiapan organisasi untuk dapat melakukan perubahan. Organizational change readiness sebagai bentuk sikap dan tindakan organisasi untuk melakukan sebuah persiapa dengan sumber daya yang dimiliki agar dengan perubahan ini, organisasi dapat berkembangan dan dapat meningkatkan eksistensi jika dapat dikelola dengan baik. Menurut Abrahamson dalam Asriani (2009) mengemukakan bahwa perubahan akan menimbulkan kejadian dramatis yang harus dihadapi oleh semuah warga organisasi. Meskipun perubahan yang terjadi dapat mengakibatkan suatu kondisi yang kurang baik, tetapi setiap organisasi haurs dapat melakukan perubahan. Hanya saja, bagaimana agar perubahan tersebut, tidak memberikan pengaruh negatif yang besar terhadap organisasi terutama UMKM. Terlebih pada perubahan yang diakibatkan oleh penerapan SAK EMKM, yang harus memberikan pengaruh positif terhadap laporan keuangan yang dibuat.

\section{Standar Akuntansi Entitas Mikro Kecil dan Menengah (SAK EMKM)}

Definisi Standar Akuntansi adalah sebuah pedoman umum dalam penyusunan laporan keuangan yang merupakan pernyataan resmi tentang masalah akuntansi tertentu yang dikeluarkan oleh lembaga yang berwenang dan berlaku pada lingkungan tertentu. Dalam perkembangan Standar Akuntansi Keuangan di Indonesia dan kebutuhan laporan keuangan entitas yang sesuai SAK yang berlaku dan ketersediaan standar akunansi yang lebih sederhana terutama pada entitas yang tidak memiliki akuntabilitas publik yang signifikan, Dewan Standar Akuntansi Keuangan (DSAK) IAI menerbitkan Standar Akuntasi Keuangan Entitas Mikro Kecil dan Menengah (SAK EMKM) yang berlaku efektif per 1 Januari 2018.

SAK EMKM merupakan standar akuntansi keuangan yang berdiri sendiri yang ditujukan kepada entitas yang memiliki akuntabilitas yang tidak signifikan seperti UMKM. SAK EMKM lebih sederhana jika dibandingkan dengan SAK ETAP, yang mana SAK ini mengatur transaksi-transaksi umum yang dilakukan oleh EMKM dan menggunaan dasar pengukuran murni dengan biaya historis (IAI, 2016). Keberadaan dan penggunaan SAK EMKM yang mulai berlaku efektif per 1 Januari 2018 diharapkan EMKM dapat menyusun laporan keuangan sederhana yang digunakan untuk mengembangkan usahanya melalui analisa kecil dalam laporan keuangan terkait strategi kedepan dan membantu kemudahan dalam pengajuan kredit dari perbankan atau lembaga keuangan lainnya yang mengisyaratkan untuk melampirkan laporan keuangan entitas.

\section{Persepsi Pengusaha UMKM}

Definisi Usaha Mikro Kecil dan Menengah (UMKM) menurut Undang-Undang Nomor 20 Tahun 2008 tentang Usaha Mikro Kecil dan Menengah masing-masing dapat didefinisikan sebagai berikut. (a) Definisi usaha mikro adalah usaha produktif yang dimiliki orang perorangan dan/atau badan usaha perorangan dengan jumlah kekayaan bersih paling banyak Rp 50.000.000 tidak termasuk tanah dan bangunan tempat usaha atau memiliki hasil penjualan tahunan paling banyak Rp 300.000.000; (b) Definisi usaha kecil adalah usaha ekonomi produktif yang berdiri sendiri yang dilakukan oleh orang perorangan atau badan usaha yang bukan merupakan anak perusahaan atau bukan cabang perusahaan yang dimiliki, dikuasai atau menjadi bagian baik langsung maupun tidak langsung dari usaha menengah atau usaha besar dengan jumlah kekayaan bersih dari Rp 50.000.000 sampai dengan paling banyak Rp 500.000.000 tidak termasuk tanah dan bangunan tempat usaha atau memiliki hasil penjualan tahunan lebih dari Rp 300.000.000 sampai dengan paling banyak Rp 2.500.000.000; (c) Definsi usaha menengah adalah usaha ekonomi produktif yang berdiri sendiri yang dilakukan oleh orang perorangan atau badan usaha yang bukan merupakan anak perusahaan atau cabang perusahaan yang dimiliki, dikuasai atau menjadi bagian baik langsung maupun tidak langsung dengan usaha kecil atau usaha besaar dengan jumlah kekayaan bersih lebih dari Rp 500.000.000 sampai dengan paling banyak Rp 10.000.000.000 tidak termasuk tanah dan bangunan tempat usaha atau memiliki hasil penjualan tahunan lebih dari Rp 2.500.000.000 sampai dengan paling banyak Rp 50.000.000.000.

Dari definisi diatas dapat disimpulkan, UMKM merupakan usaha yang didirikan, dimiliki, dan dikembangkan oleh orang/perorangan atau badan usaha yang bukan anak perusahaan atau cabang perusahaan yang dimiliki langsung atau tidak langsung dan memiliki kriteria sebagai UMKM. UMKM ini dikelola dan dikembangkan oleh pengusaha atau pelaku UMKM sesuai dengan kemampuan personal dan keadaan UMKM. Pengelolaan yang dimaksud baik berkaitan dengan pengelolaan aktivitas operasional/manajemen usaha maupun keuangan/akuntasi UMKM. Pengelolaan aktivitas operasional dan 
keuangan UMKM, dijalankan secara bersama-sama untuk mengetahui seberapa jauh/banyak UMKM telah melakukan aktivitas dan keadaan keuangan usaha sehingga Pengusaha UMKM memiliki gambaran umum terkait usahanya.

Perpesi dapat diartikan sebagai cara pandang seseorang terhadap sesuatu baik objek atau peristiwa yang dilihat atau dialaminya dan dapat mempengaruhi sikap seseorang. Selain itu, perpsesi dapat didefinisikan sebagai proses pemberian arti atau makna terhadap lingkungan, yang artinya persepsi melingkupi penafsiran objek, stimulis, pengorganisasian stimulus dan pemberian penafsiran terhadap stimulus yang telah koordinir dengan mempengaruhi perilaku dan perubahan sikap (Mangkunegara dalam Tarmizi dan Sartika, 2013). Syarat-syarat dapat terjadinya persepsi adalah a) adanya objek, b) adanya perhatian sebagai langkah pertama untuk mengadakan persepsi, c) adanya alat indra sebagai reseptor penerima stimulus, dan d) saraf sensoris sebagai alat untuk meneruskan stimulus ke otak (Sunaryo, 2004).

Persepsi dalam penelitian ini dapat diartikan bahwa pandangan pengusaha UMKM terhadap objek atau kejadian di dalam masyarakat yakni berkaitan dengan penerapan standar akuntansi keuangan entitas mikro kecil dan menengah (SAK-EMKM). Persepsi pengusaha UMKM berkaitan dengan persepsi kegunaan dan persepsi kemudahan penggunaan SAK-EMKM dalam laporan keuangan.

\section{Organizational Change Readiness}

Organizational change readiness atau kesiapan organisasi untuk berubah merupakan sebuah proses yang harus dijalankan atau dialami oleh organisasi tersebut untuk suatu kemajuan yang diinginkan terjadi pada masa depan yang sesuai dengan tujuan yang hendak dicapai. Sebuah organisasi tidak akan menutup diri terhadap perubahan yang terjadi pada lingkungan sekitarnya sehinga dapat memenangkan sebuah persaingan dan eksistensi. Menurut Korbangyang dan Ussahawanitchakit dalam Hami (2016) menyatakan bahwa keberhasilan suatu bisnis dapat ditentukan oleh kesiapan dari organisasi tersebut untuk melakukan perubahan.

Kesiapan organisasi untuk berubah dipengaruhi oleh sumber daya manusia yang dimiliki, sumber daya modal dan lingkungan sekitar. Menurut Susanto (2009: 144), kesiapan berubah terfokus pada dua hal yakni kompetensi yang mendukung perubahan, dan komitmen untuk berubah. Kedua faktor ini menjadi pendukung sebuah perubahan dapat dilakukan dalam organisasi secara teridentifikasi. Selain itu, adanya aspek kesiapan perubahan pada organisasi yang dapat menunjukkan organisasi tersebut siap untuk berubah atau sebaliknya. Menurut Hami (2016), ketujuh aspek tersebut antara lain a) persepsi terhadap upaya perubahan (perception toward change efforts), b) visi untuk berubah (vision for change), c) rasa saling percaya dan menghargai (mutual trust dan respect), d) keterlibatan dalam perubahan (change initiatives), e) dukungan manajemen (management support), f) penerimaan (acceptance) dan g) pengelolaan proses perubahan (the organization manage the change process). Dalam mempersiapkan sebuah perubahan pada organisasi (Organizational change readiness) tentunya menentukan target perubahan itu sendiri yakni terkait dengan sumber daya manusia, sumber daya fungsional, kemampuan teknologi, dan kemampuan organisasi. Target perubahan yang ditentukan tersebut, akan membawa sebuah perubahan yang terarah dari organisasi tersebut.

\section{Rumusan Hipotesis}

Pengaruh Persepsi Pengusaha UMKM terhadap Penerapan Standar Akuntansi Keuangan Entitas Mikro Kecil dan Menengah

Persepsi pengusaha UMKM tentang SAK EMKM didefinisikan sebagai pandangan atau pendapat pengusaha UMKM terkait penerapan SAK EMKM pada usahanya yang digunakan untuk pengusaha didalam pengelolaan keuangan dan informasi didalam pengambilan keputusan usaha. Persepsi ini berkaitan dengan kegunaan dan kemudahan penggunaan SAK EMKM sehingga pembuatan pencatatan/pembukuan sampai pada laporan keuangan tidak menyulitkan pengusaha UMKM untuk memahai dan membuat sebuah laporan yang sangat berguna bagi usahanya. Semakin baik persepsi dari pelaku UMKM tentang akuntansi, maka semakin baik pula untuk menggunakan akuntansi untuk tujuan pelaporan keuangan dan informasi untuk keputusan usaha. Berdasarkan hasil penelitian tersebut, maka dapat dirumuskan hipotesis penelitian sebagai berikut.

$\mathrm{H}_{1}$ : Persepsi Pengusaha UMKM berpengaruh terhadap Penerapan Standar Akuntansi Keuangan Entitas Mikro Kecil dan Menengah.

Pengaruh Organizational Change Readiness terhadap Penerapan Standar Akuntansi Keuangan Entitas Mikro Kecil dan Menengah

Korbang yang dan Ussahawanitchakit dalam Hami (2016) menyatakan bahwa keberhasilan suatu bisnis dapat ditentukan oleh kesiapan dari organisasi tersebut untuk melakukan perubahan. Artinya, kesiapan organisasi untuk perubahan akan berdampak pada keberhasilan suatu organisasi menerima 
segala hasil dari perubahan tersebut. Begitu pula organizational change readiness pada penerapan SAK EMKM, yang mana persiapan organisasi untuk melakukan perubahan sangat dibutuhkan didalam penerapannya. Hal ini dikarenakan, ketika suatu usaha atau UMKM memiliki kesiapan untuk menerapkan SAK EMKM, maka UMKM mampu menerapkan perubahan didalam usahanya terkait dengan pencatatan/pembukuan hingga laporan keuangan yang disesuaikan dengan standar akuntansi yang berlaku. Penelitian yang dilakukan (Harimurti dan Mariatin, 2014 ) menyatakan bahwa kesiapan berubah memiliki pengaruh positif signifikan terhadap penerapan performance management system. Performance management system ini berpedoman dari informasi-informasi yang relevan didalam pengelolaan usaha salah satunya laporan keuangan yang disesuaikan dengan standar yang berlaku, sehingga memberikan informasi yang relevan dan mengarah pada pengambilan keputusan. Dengan demikian, kesiapan untuk berubah memiliki pengaruh positif signifikan terhadap pembelajaran organisasional. Berdasarkan hasil penelitian tersebut, maka dapat dirumuskan hipotesis penelitian sebagai berikut.

$\mathrm{H}_{2}$ : Organizational cahnge readines berpengaruh terhadap Penerapan Standar Akuntansi Keuangan Entitas Mikro Kecil dan Menengah.

\section{Metode}

Penelitian ini merupakan penelitian kuantitatif dengan menggunakan metode survey. Desain penelitian ini merupakan suatau rancangan penelitian yang dilakukan untuk menguji dengan cermat dan teliti yang berkaitan dengan objek penelitian sesuai dengan kondisi lapangan atau pernyataan tertentu oleh responden. Data kuantitatif dalam penelitian ini adalah persepsi Pengusaha UMKM, organizational change readiness, dan penerapan standar akuntansi entitas mikro kecil dan menengah (SAK-EMKM).

Populasi dalam penelitian ini adalah Usaha Mikro Kecil dan Menengah (UMKM) di Kabupaten Buleleng yang terdaftar di Dinas Koperasi Usaha Kecil dan Menengah Kabupaten Buleleng yang berjumlah 32.756 UMKM (Dinas Koperasi Usaha Kecil dan Menengah dalam diskopukm.bulelengkab.go.id diakses tanggal 3 Agustus 2018. Teknik pengambilan sampel penelitian ini adalah dengan teknik probability sampling dengan simple random sampling yang merupakan pengambilan anggota sampel dari populasi yang dilakukan secara acak tanpa memperhatikan strata yang ada dalam populasi (Sugiyono, 2017:82). Responden dalam penelitian ini adalah Pengusaha UMKM atau Karyawan yang mengetahui pencatatan/pembukuan UMKM. Hal ini dikarenakan tingkat pengembalian kuesioner dari jawaban responden dapat dipahami dengan baik dan cermat, dikembalikan dengan cepat sehingga akan meminimalkan terjadinya jawaban bias (respon bias). Dengan demikian penentuan jumlah sampel menggunakan rumus Slovin (Wahyudi, 2017:17) yaitu:

Keterangan:

$$
n=\frac{N}{1+N(d)^{2}}
$$

$\mathrm{n}=$ ukuran sampel

$\mathrm{N}=$ ukuran populasi

$\mathrm{d}=$ tingkat kesalahan yang dipilih ini yaitu :

Berdasarkan rumus slovin diatas, maka perhitungan dan hasil jumlah sampel minimal penelitian

$$
n=\frac{32.756}{1+32.756 .0,01}=99,69=100 \text { (dibulatkan) }
$$

Pengumpulan data dalam penelitian ini menggunakan metode survey dengan alat yang digunakan berupa kuesioner kepada responden. Responden dalam penelitian ini adalah Pengusaha UMKM atau Karyawan yang mengetahui/diberikan kepercayaan untuk pencatatan/pembukuan UMKM.

Definisi Operasional Variabel

Persepsi Pengusaha UMKM

Persepsi dalam penelitian ini dapat diartikan bahwa pandangan pengusaha UMKM terhadap objek atau kejadian di dalam masyarakat yakni berkaitan dengan penerapan standar akuntansi keuangan entitas mikro kecil dan menengah (SAK-EMKM). Menurut Walgito dalam Candra, dkk (2017), persepsi seseorang dapat dipengaruhi oleh ketersediaan informasi sebelumnya, kebutuhan, pengalaman masa lalu, emosi, impresi, dan konteks lingkungan. Indikator penelitian ini mengembangkan indikator dari Afianti (2017), yang mana persepsi pengusaha UMKM berkaitan dengan persepsi kegunaan dan persepsi kemudahan 
penggunaan SAK-EMKM dalam laporan keuangan. Indikator tersebut dikembangkan menjadi 13 item pernyataan dengan skala antara 1 "Sangat Tidak Setuju" sampai 5 "Sangat Setuju".

\section{Organizational Change Readiness}

Organizational change readiness atau kesiapan organisasi untuk berubah merupakan sebuah proses yang harus dijalankan atau dialami oleh organisasi tersebut untuk suatu kemajuan yang diinginkan terjadi pada masa depan yang sesuai dengan tujuan yang hendak dicapai. Menurut Korbangyang dan Ussahawanitchakit dalam Hami (2016) menyatakan bahwa keberhasilan suatu bisnis dapat ditentukan oleh kesiapan dari organisasi tersebut untuk melakukan perubahan. Variabel Organizational change readiness diukur melalui 7 dimensi atau indikator dari Hami (2016) yang terdiri dari a) persepsi terhadap upaya perubahan (perception toward change efforts), b) visi untuk berubah (vision for change), c) rasa saling percaya dan menghargai (mutual trust dan respect), d) keterlibatan dalam perubahan (change initiatives), e) dukungan manajemen (management support), f) penerimaan (acceptance) dan g) pengelolaan proses perubahan (the organization manage the change process).

\section{Penerapan Standar Akuntansi Keuangan Entitas Mikro Kecil dan Menengah (SAK EMKM)}

Penerapan SAK EMKM didefinisikan dalam penelitian ini adalah penggunaan standar akuntansi keuangan ke dalam entitas bisnis yang digunakan untuk pelaporan keuangan suatu entitas. Pelaporan keuangan yang sesuai standar akuntansi keuangan yang berlaku akan memberikan manfaat bagi pemakai dan pengguna laporan tersebut. Standar Akuntansi Keuangan yang berlaku untuk UMKM saat ini adalah SAK EMKM, yang mana standar ini mengisyaratkan UMKM dapat menerapkan standar akuntansi tersebut yang telah disederhakankan dari SAK sebelumnya. Terkait laporan keuangan yang dibuat UMKM terdiri dari laporan posisi keuangan pada akhir periode, laporan laba rugi selama periode dan catatan atas laporan keuangan yang berisi tambahan dan rincian pos-pos tertentu yang relevan (IAI, 2016). Tujuan dari penyusun laporan keuangan sesuai SAK EMKM yang digunakan untuk mengembangkan usahanya melalui analisa kecil dalam laporan keuangan terkait strategi kedepan dan membantu kemudahan dalam pengajuan kredit dari perbankan atau lembaga keuangan lainnya yang mengisyaratkan untuk melampirkan laporan keuangan entitas. Indikator yang digunakan dalam penelitian ini dikembangkan dari indikator dari Pradipta dan Supadmi (2015) yang terdiri dari akuntabilitas, tujuan, dan karakteristik kelengkapan informasi dalam standar akuntansi keuangan yang disesuaikan dengan isyarat dari SAK EMKM.

Dalam menguji pengaruh persepsi Pengusaha UMKM dan organizational change readiness terhadap Penerapan Standar Akuntansi Keuangan Entitas Mikro Kecil dan Menengah, analisis data yang digunakan adalah uji regresi liniear berganda dengan menggunakan software Statistical Package for Social Sciense (SPSS) v.20. Model regresi liniear berganda dapat disebut sebagai model yang baik jika model tersebut memenuhi beberapa asumsi yang disebut dengan asumsi klasik. Sebelum masuk ke uji regresi ini, terlebih dahulu dilakukan uji kualitas data yang terdiri dari uji validitas dan uji reliabilitas. Uji Validitas menggunakan Pearson Correlation yang menghitung korelasi antara skor masing-masing butir pernyataan dengan skor total. Variabel dikatakan valid apabila memiliki nilai signifikansi lebih besar dari 0,05. Sedangkan dalam uji reliabilitas, variabel dikatakan reliabel apabila memiliki nilai cronbach alpha lebih besar dari 0,60 (Ghozali, 2012). Kemudian, setelah data tersebut dikatakan valid dan reliable maka dilanjutkan dengan uji asumsi klasik yang terdiri dari uji normalitas, uji multikolinearitas, dan uji heteroskedastisitas. Uji normalitas dilakukan menggunakan Kolmogorov Smirnov dengan koefisien Asymp. Sig lebih besar dari 0,05 (Ghozali, 2012). Untuk mendeteksi adanya multikolinearitas digunakan nilai tolerance $=0,10$ dan Variance Inflation Factor (VIF) $=10$ (Ghozali, 2012). Pengujian heteroskedastisitas menggunakan uji glejser dengan meregresikan nilai absolute residual dengan variabel independen yang digunakan. Jika memiliki nilai signifikansi diatas 0,05, dikatakan tidak terjadi heteroskedastisitas (Ghozali, 2011). Setelah melewati tahapan uji tersebut, maka selanjutnya dilakukan uji regresi linier berganda yang bertujuan untuk memprediksi besar variabel dependen dengan menggunakan data variabel independen yang sudah diketahui besarnya. Model regresi liniear berganda dapat diformulasikan dalam rumus berikut ini.

Keterangan:

$$
\mathbf{Y}=\mathbf{a}+\mathbf{b}_{1} \mathbf{X}_{1}+\mathbf{b}_{2} \mathbf{X}_{2}+\mathbf{e}
$$

$\mathrm{Y} \quad=$ Penerapan Standar Akuntansi Keuangan Entitas Mikro Kecil dan Menengah

$\mathrm{a} \quad=$ Konstanta

$\mathrm{X}_{1} \quad=$ Persepsi Pengusaha UMKM

$\mathrm{X}_{2} \quad$ = Organizational change readiness

$\mathrm{e} \quad=$ erro term (Standar Error)

Dalam pengujian hipotesis penelitian ini menggunakan ujit (secara parsial). Uji ini bertujuan untuk menunjukkan bahwa seberapa jauh pengaruh satu variabel bebas secara individual dalam menjelaskan 
variasi variabel terikat. Kriteria yang digunakan untuk membuat keputusan terhadap hasil uji hipotesis berdasarkan tingkat signifikansi sebesar 0,05 atau 5\%. Dalam uji ini terlebih dahulu dilakukan perumusan hipotesis sebagai berikut.

a. $\mathrm{H}_{0}: \beta \mathrm{i}=0$, artinya variabel independen $(\mathrm{X})$ tidak berpengaruh signifikan terhadap variabel dependen $(\mathrm{Y})$.

b. $\mathrm{H}_{0}: \beta \mathrm{i} \neq 0$, artinya variabel independen $(\mathrm{X})$ berpengaruh signifikan terhadap variable dependen $(\mathrm{Y})$.

\section{Hasil dan pembahasan}

Dalam penelitian ini, peneliti melakukan penyebaran kuesioner secara langsung kepada responden yakni Pengusaha UMKM atau yang mewakili dan memiliki pemahaman terhadap pencatatan/pembukuan serta laporan keuangan di Kabupaten Buleleng yang menggunakan teknik pengambilan sampel probability sampling dengan simple random sampling. Jumlah kuesioner yang disebar sebanyak 100 kuesioner dengan 100 responden. Kuesioner kembali sebanyak 87 kuesioner sehingga sebanyak kuesioner ini yang dapat diolah selanjutnya. Karakteristikr responden berdasarkan atas jenis kelamin yang menunjukkan jenis kelamin laki-laki sebanyak 62\% dan perempuan sebanyak $25 \%$.

Berdasarkan hasil pengujian pertama yakni uji kualitas data yang terdiri dari uji validitas dan reliabilitas, menunjukkan bahwa setiap item pernyataan pada kuesioner dalam penelitian ini dapat dikatakan valid, yang mana Setiap item pernyataan pada kuesioner berada pada signifikansi (Sig. (2-tailed)) $\leq$ 0,05 dan semua variabel memiliki nilai Cronbach's Alpha lebih besar dari 0,60. Kemudian, dilanjutkan dengan pengujian kedua yakni uji asumsi klasik yang terdiri dari uji normalitas, uji multikolinearitas dan uji heteroskedastisitas. Hasil uji normalitas menggunakan uji statistik dengan Kolmogorov-Smirnov $Z$ yang menunjukkan hasil nilai Asymp. Sig. (2-tailed) sebesar 0,522 lebih besar dari 0,05 sehingga data yang digunakan dalam penelitian ini telah berdistribusi normal. Hasil uji Multikolinearitas menunjukkan nilai tolerance semua variabel penelitian lebih besar dari 0,10 dan nilai VIF semua variabel penelitian memiliki nilai kurang dari 10 sehingga dapat disimpulkan bahwa tidak terjadi gejala multikolinearitas antar variabel bebas. Hasil uji heteroskedastisitas menunjukkan bahwa semua variabel memiliki nilai signifikansi lebih besar dari 0,05 sehingga tidak ada satupun variabel tersebut terjadi gejala heteroskedastisitas, dengan kata lain dapat dikatakan model regresi tidak mengandung heterokedastisitas.

Hasil uji regresi variabel penelitian ini menyatakan bahwa model summary menunjukkan bahwa besarnya $\mathrm{R}^{2}$ sebesar 0,176, artinya sebesar 17,6\% variabel Penerapan Standar Akuntansi Keuangan Entitas Mikro Kecil dan Menengah dapat dijelaskan oleh variasi variabel independen yaitu persepsi Pengusaha UMKM dan organizational change readiness. Sedangkan sisanya dijelaskan oleh sebab-sebab lain diluar model. Hasil perhitungan uji hipotesis dengan uji signifikansi parameter individual (uji t) didapatkan hasil sebagai berikut

Tabel 4.1 Uji Signifikansi Parameter Individual (Uji Statistik t)

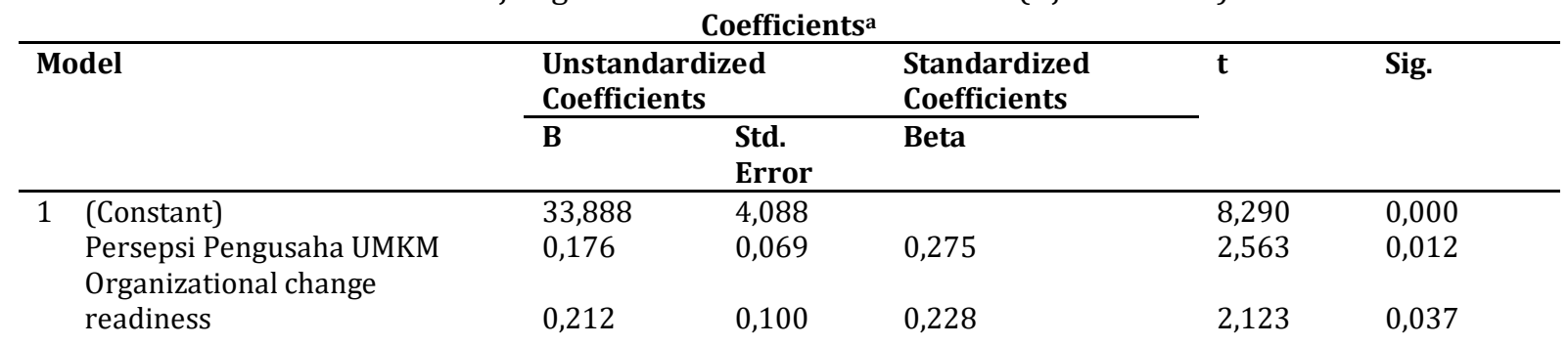

a. Dependent Variable: Penerapan SAK EMKM

Berdasarkan hasil uji signifikansi parameter individual (uji statistik t) diatas, menunjukkan bahwa variabel persepsi Pengusaha UMKM memiliki nilai coefficients nilai t hitung sebesar 2,563 dan memiliki nilai signifikansi sebesar 0,012 lebih kecil dari 0,05, maka $\mathrm{H}_{1}$ diterima. Sedangkan variabel organizational change readiness memiliki nilai coefficients nilai t hitung sebesar 2,123 dan memiliki nilai signifikansi sebesar 0,037 lebih kecil dari 0,05, maka $\mathrm{H}_{2}$ diterima.

Berdasarkan hasil uji analisis data, maka didapatkan hasil bahwa hipotesis 1 (satu) diterima artinya variabel persepsi pengusaha UMKM berpengaruh signifikan positif terhadap penerapan standar akuntansi keuangan entitas mikro kecil dan menengah (SAK EMKM). Persepsi pengusaha UMKM yang baik terhadap penerapan SAK EMKM, akan dapat memberikan penerapan yang baik sesuai isyarat standar akuntansi tersebut pada UMKM atau kata lainnya persepsi pengusaha UMKM yang baik, maka SAK EMKM 
dapat diterapkan dengan baik. Jadi, persepsi pengusaha UMKM memiliki peran strategis didalam penerapan SAK EMKM terutama UMKM di Buleleng. Persepsi setiap individu mengenai objek sangat tergantung pada kerangka ruang dan waktu yang berbeda (Pradipta dan Supadmi, 2015). Namun demikian, persepi pengusaha UMKM terhadap SAK EMKM dalam hal ini terkait dengan adanya persepsi kegunaan dan kemudahan penggunaan penerapan SAK EMKM sehingga nantinya diharapkan persepsi tersebut memberikan pemahaman yang sama terkait SAK EMKM yang diterapkan. Persepsi kegunaan SAK EMKM dapat diartikan bahwa persepsi pengusaha UMKM di Buleleng terhadap penerapan standar akuntansi tersebut diyakini SAK EMKM memberikan pedoman yang jelas dan sederhana dalam laporan keuangan jika dibandingkan dengan SAK lainnya sehingga laporan keuangan yang dibuat UMKM dapat digunakan sebagai bahan informasi dalam pengambilan keputusan bisnis, memberikan manfaat terkait perencanaan masa mendatang, memberikan gambaran terkait kondisi keuangan usaha dan yang terpenting pada UMKM bahwa laporan keuangan dapat digunakan sebagai bahan pendukung dalam pengajuan kredit di perbankan. Sedangkan, dalam persepsi kemudahan penggunaan SAK EMKM yang diterapkan UMKM di Buleleng menunjukkan bahwa SAK EMKM yang diterapkan diyakini memberikan kemudahan penggunaan dan dapat dipelajari, yang mana SAK EMKM memuat pengaturan akuntansi yang lebih sederhana dari SAK ETAP (IAI, 2016).

Pada hipotesis 2 (kedua) dinyatakan diterima, artinya variabel organizational change readiness berpengaruh positif signifikan terhadap penerapan standar akuntansi keuangan entitas mikro kecil dan menengah (SAK EMKM). Organizational change readiness menjadi langkah awal dalam menerapkan SAK EMKM. Semakin baik organizational change readiness dalam hal ini berkaitan dengan aspek organizational change readiness, maka semakin mudah dan lancar untuk menerapkan SAK EMKM. Organizational change readiness dianggap sebagai faktor penting dalam keberhasilan perubahan sehingga perlu menjadi perhatian penting apabila akan melakukan perubahan (Rafferty, et al dalam Diab, et al, 2018). Hal ini dapat diartikan bahwa, organizational change readiness yang dimiliki UMKM sangat diperlukan dalam perubahan SAK terlebih pada SAK EMKM, yang mana perubahan yang terjadi nantinya dapat memberikan manfaat yang baik. Begitu pula pada penerapan SAK EMKM pada UMKM di Buleleng bahwa adanya SAK EMKM ini, UMKM terutama di Buleleng dapat melakukan perubahan terkait aspek akuntansi baik pencatatan/pembukuan maupun laporan keuangan. Perubahan dapat terjadi apabila perubahan tersebut memberikan change valance yang akan didapatkan oleh perubahan tersebut (Harimurti dan Mariatin, 2014 ). Artinya bahwa organizational change readiness yang disiapkan UMKM untuk penyesuaian SAK akan dapat dilakukan apabila kesiapan tersebut memberikan perubahan yang memiliki keuntungan bagi UMKM itu sendiri. Dalam penerapan SAK terutaman SAK EMKM, UMKM sebagai pengguna menapatkan keuntungan yang akan didapatkan, yang mana SAK EMKM lebih sederhana dari SAK EMKM yang memuat aturan transaksi yang umum dilakukan oleh UMKM dan dilihat dari dasar pengukuran menggunakan biaya historis sehingga mudah untuk diterapkan dengan sumber daya yang dimiliki UMKM (IAI, 2016). Selain itu, mengikuti SAK EMKM dalam penyusunan laporan keuangan, mempermudah akses permodalan pada perbankan.

\section{Simpulan dan saran}

Berdasarkan hasil dan uraian diatas, maka dapat disimpulkan bahwa persepsi pengusaha UMKM terkait persepsi kegunaan dan persepsi kemudahan penggunaan semakin baik sehingga SAK EMKM dapat diterapkan dengan baik. Artinya bahwa persepsi kegunaan SAK EMKM sangat diperlukan dalam UMKM terkait tersediaan laporan keuangan yang dapat digunakan UMKM dan adanya proses yang mudah dan sederhana dalam penggunaan SAK EMKM sehingga UMKM akan dapat menerapkan SAK EMKM sesuai isyarat standar tersebut. Dengan kata lainnya bahwa persepi pengusaha UMKM memiliki pengaruh signifikan positif terhadap penerapan SAK EMKM. Sedangkan organizational change readiness memiliki pengaruh signifikan positif terhadap penerapan SAK EMKM, yang mana dapat diartikan bahwa adanya kesiapan yang baik dalam organisasi yang dicerminkan dari aspek organizational change readiness itu sendiri, maka SAK EMKM dapat diterapkan dengan baik dan lancar.

Implikasi penelitian ini adalah penelitian ini diharapkan memberikan kontribusi kepada pihak yang berkepentingan baik Pemerintah Pusat atau Kemeneterian terkait dan DSAK IAI sebagai penyusun standar akuntansi, yang mana perkembangan UMKM harus diimbangi dengan pengetahuan UMKM terhadap akuntansi melalui sosialisasi atau pelatihan akuntansi yang dapat memberikan manfaat dalam pengelolaan keuangan sehingga laporan keuangan yang dibuat dapat digunakan UMKM. Selain itu, diperlukan peran aktif dari IAI untuk survei lapangan dengan memberikan kesamaan persepsi dan organizational change readiness yang maksimal penggunaan SAK EMKM sehingga UMKM dapat menerapkan sesuai standar akuntansi. Bagi UMKM, pentingnya untuk menerapkan SAK EMKM dengan persepsi yang baik dan , karena SAK EMKM telah mengatur transaksi umum yang dilakukan dan hasil dari transaksi ini dibuatkan laporan 
keuangan yang digunakan untuk akses permodalan perbankan salah satu syaratnya dan memberikan gambaran umum terkait kondisi keuangan usaha.

Keterbatasan penelitian ini adalah dalam metode pengumpulan data digunakan metode survey dengan menggunakan kuesioner yang disebarkan kepada responden/pengusaha UMKM atau yang mewakili sehingga kemungkinan adanya perbedaan persepsi atau interpretasi yang berbeda antara respoden atau UMKM dengan peneliti sehingga diperlukan konfirmasi kembali terkait pernyataan pada kuesioner agar jawaban atas pernyataan dapat diketahui lebih dalam. Selain itu, penelitian ini dilakukan di Kabupaten Buleleng sehingga diperlukan pengembangan populasi penelitian agar penelitian dapat digeneralisasi secara menyeluruh dan dari hasil pengujian ditemukan bahwa masih banyak faktor yang mempengaruhi penerapan SAK EMKM, yang mana penelitian selanjutnya dapat memakai variabel lainnya yang diduga kuat dalam mempengaruhi penerapan SAK EMKM.

\section{Daftar Rujukan}

Afianti, Puspita Putri. 2017. Faktor-Faktor yang Mempengaruhi Penerapan Standar Akuntansi Keuangan Entitas Tanpa Akuntabilitas Publik (SAK ETAP) pada UMKM di Kabupaten Bogor. Skripsi. Fakultas Ekonomi Universitas Negeri Jakarta.

Amad. 2017. Peranan Penting UMKM di Masa Mendatang. [Online]. Tersedia di http://harian.analisadaily.com/ekonomi/news/peran-penting-umkm-di-masamendatang/326556/2017/02/25. Diakses pada tanggal 31 Juli 2018.

Astiani, Yulia. 2017. Pengaruh Persepsi Pelaku Usaha Mikro Kecil dan Menengah tentang Akuntasi, Pengetahuan Akuntansi, dan Skala Usaha terhadap Penggunaan Informasi Akuntansi. Skripsi. Program Studi Akuntansi, Fakultas Ekonomi, Universitas Negeri Yogyakarta.

Budianto, Arif. 2018. Banyak UKM Tumbang di Tahun Pertama, ini Penyebabnya. [Online]. Tersedia di https://ekbis.sindonews.com/read/1336935/34/banyak-ukm-tumbang-di-tahun-pertama-inipenyebabnya-1536488439, Diakses pada tanggal 11 September 2018.

Candra, I Wayan, dkk. 2017. Psikologi Landasan Keilmuan Praktik Keperawatan Jiwa. Yogyakarta : Penerbit ANDI.

Diab, Gehan Mohammaed, et al. 2018. Organizational Change Readiness and Manager Behavior in Managing Change. Journal of Nursing Education and Practice 8 (7): 68-77.

Dinas Koperasi, Usaha Kecil, dan Menengah Kabupaten Buleleng. 2018. [Online]. Tersedia di www.diskopukm.bulelengkab.go.id. Diakses pada tanggal 3 Agustus 2018.

Fatimah, Ari Nurul dan Singgih Wijayana. 2017. Analisis Kesiapan Lima Usaha Kecil dalam Implementasi SAK EMKM di Kabupaten Purworejo. Tesis. Magister Akuntansi, Fakultas Ekonomika dan Bisnis, Universitas Gadjah Mada.

Fatwa. 2016. Analisis Penerapan SAK ETAP pada Usaha Kecil Menengah (UKM) Penggilingan Padi. Jurnal Kajian Ilmiah Akuntansi Fakultas Ekonomi UNTAN 5 (4).

Ghozali, Imam. 2011. Analisis Multivariate Dengan Program SPSS. Semarang: Badan Penerbit Universitas Diponegoro.

Ghozali, Imam. 2012. Analisis Multivariate Dengan Program SPSS. Semarang: Badan Penerbit Universitas Diponegoro.

Hami, Azhar El. 2016. Hubungan antara Kepribadian, Kesiapan Organisasi untuk Berubah dan Kriteria Universitas Kelas Dunia. PSYMATHIC: Jurnal Ilmiah Psikologi 3 (1): 95-112.

Harimurti, Etti dan Emmy Mariatin. 2014. Pengaruh Kesiapan Berubah, Komitmen terhadap Organisasi dan Komunikasi tentang perubahan organisasi terhadap penerapan Performance Management System. Jurnal Analitika Magister Psikologi Uma, 6 (1): 27-36.

Ikatan Akuntan Indonesia. 2016. Pengertian standar Akuntansi Keuangan Entitas Tanpa Akuntabilitas Publik (SAK ETAP). [Online]. Tersedia di http://iaiglobal.or.id/v03/standar-akuntansikeuangan/etap. Diakses pada tanggal 5 Agustus 2018.

Ikatan Akuntan Indonesia. 2016. Standar Akuntansi Keuangan Entitas Mikro, Kecil dan Menengah. Jakarta: Ikatan Akuntan Indonesia. 
Kementerian Koperasi dan Usaha Kecil dan Menengah Indonesia. _. [Online]. Tersedia di www.depkop.go.id. Diakses pada tanggal 3 Agustus 2018.

Menteri Hukum dan Hak Asasi Manusia Republik Indonesia. 2008. Undang-Undang Republik Indonesia Nomor 20 Tahun 2008 tentang Usaha Mikro, Kecil dan Menengah.

Penggunaan dan Kegunaan pada Implementasi SAK ETAP (Studi Empiris pada UKM di Denpasar Utara). EJurnal Akuntansi Universitas Udayana 13(3): 857-887).

Pradipta, I Gusti Ngr. Aditya dan Ni Luh Supadmi. 2015. Pengaruh Persepsi Kemudahan

Robbins, Stephen P dan Timothy A. Judge. 2008. Perilaku Organisasi. Edisi 12. Jakarta : Salemba Empat.

Rudiantoro, Rizki dan Sylvia Veronica Siregar. 2012. Kualitas Laporan Keuangan UMKM serta Prospek Implementasi SAK ETAP. Jurnal Akuntansi dan Keuangan Indonesia 9 (1): 1-12.

Sarwono, Jonathan. 2010. Pintar Menulis Karangan Ilmiah-Kunci Sukses dalam Menulis Ilmiah. Yogyakarta : Penerbit ANDI.

Sugiyono. 2017. Metode Penelitian Kuantitatif, Kualitatif, dan R\&D. Bandung:Alfabeta.

Sunaryo. 2004. Psikologi untuk Keperawatan. Jakarta: Buku Kedokteran EGC.

Susanto, A.B. 2009. Super Leadership-Leading Other to Lead. Jakarta: Gramedia Pustaka Utama.

Tarmisi, Rosmiaty dan Ni Luh Sartika Bugawanti. 2013. Pengaruh Perpsesi Pengusaha Kecil dan Menengah terhadap Penggunaan SAK ETAP di Kota Bandar Lampung (Studi pada sentra kripik segalamider bandar lampung. Jurnal Akuntansi dan Keuangan 4 (2).

Wahyudi, Setyo Tri. 2017. Statistika Ekonomi-Konsep, Teori dan Penerapan. Malang: UB Press. 